\title{
Randomized Control Trial Complementary Therapy Garlic (Allium Sativum Linn) Capsules In Hypertension Patients
}

\author{
Ana Amalia ${ }^{1 *}$ and Fendri Luukmanto ${ }^{1}$ \\ ${ }^{1}$ Program Studi S1 Farmasi, Stikes Karya Putra, Indonesia \\ *corresponding author : ana.amalia@stikes-kartrasa.ac.id
}

\begin{abstract}
Hypertension is a type of disease that is difficult to control, because in some cases there are no signs and symptoms that appear. Giving pharmacological therapy is not enough to control the patient's blood pressure, so it is necessary to do research related to complementary therapy. Complementary therapy that can be given can be in the form of garlic capsules which contain allicin which is efficacious in lowering blood pressure. The purpose of this study was to determine the effect of complementary therapy with garlic capsules on the value of MAP- in patients with uncontrolled hypertension. The study design was a -RCTMAP measurements were carried out pre-post therapy at weeks $0,1,2,3$, and 4 .. The sampling technique used simple random sampling, the sample was divided into a control group (placebo) and a treatment group each consisting of 30 people. The results of this study With paired t-test analysis showed that the average result of the decrease in MAP in the garlic capsule group was 20.23 with a P Value of 0.000 , which means that there is a significant difference between the MAP value before and after administration of garlic capsules. The placebo group had a P Value of 0.258 , this shows that there is no difference in MAP before and after giving placebo. The conclusion of this study is that giving garlic capsules can reduce blood pressure in hypertensive patients.Further research is needed regarding the cost analysis of the comparison of complementary therapy with conventional medicine.
\end{abstract}

Keywords: Hypertension, Garlic, Mean Arterial Pressure, Allium sativum Linn.

\section{Introduction}

Hypertension is defined as arterial blood pressure that continues to increase $>120 / 80$ mmHg (DiPiro et al., 2021). Hypertension is the 5th largest type of chronic disease at all ages (Kementerian Kesehatan RI. Pusat Data Informasi, 2014). World Health Organization in 2015, shows that around 1.13 billion people in the world have hypertension. The number of people with hypertension is estimated to continue to increase every year and by 2025 there will be 1.5 billion people suffering from hypertension. Dinas Kesehatan Provinsi Jawa Timur (2017) stated that the prevalence of hypertension was 935,736 people; consisting of 387,913 men and 547,823 women. The prevalence of hypertension in 32 puskesmas in Tulungagung increased from 55,782 people in 2018 to 58,562 people in 2019; an increase of 2,780 people in one year. Bangun Jaya Health Center from 2018-2019 experienced the 6th highest increase in the number of hypertension patients out of 32 health centers in Tulungagung (Dinas Kesehatan Kabupaten Tulungagung, 2020). Sanan Village is one of the fostered villages of the Bangun Jaya Public Health Center which has the first collaboration program between pharmacists and doctors in controlling hypertension and diabetes.

Hypertension is defined as a silent killer, because in some cases there are no signs and symptoms that appear but the patient has high blood pressure so that if not treated properly it can 
lead to complications and death (Kowalski, 2010; Smeltzer and Bare, 2013). Treatment of hypertension is divided into pharmacological and non-pharmacological treatment. Pharmacological treatment is carried out by using antihypertensive drugs such as ACEi (Angiotensin-converting Enzyme Inhibitors), ARBs (Angiotensin Receptor Blockers), diuretics, beta blockers, and CCBs (Calcium Channel Blockers). Non-pharmacological management is done by losing weight, limiting salt intake, doing sports that can be tolerated by cardiovascular health; for 30 minutes five times a week, limit alcohol consumption, and don't smoke. The principle of hypertension management is to maintain normal blood pressure and prevent complications, both short and long term (Kidney Disease Improving Global Outcomes, 2012).

The provision of pharmacological therapy is felt to be insufficient to control the patient's blood pressure, so it is necessary to do research related to complementary therapies. Various studies have been developed to lower blood pressure, including complementary therapies. Complementary therapy is a complementary therapy in which traditional medicine is combined with modern medicine (Widyatuti, 2008). One of the complementary therapies to lower blood pressure is to use the garlic plant. Garlic contains 33 sulfur compounds, 17 amino acids and minerals such as selenium. The allicin content in garlic has the effect of lowering blood pressure (Febyan et al., 2015; Ashraf et al., 2013). Therefore, researchers are interested in knowing the effect of complementary therapy with garlic (Allium sativum Linn) capsules on patients with uncontrolled hypertension.

\section{Methods}

This study used a double-blind Randomized Controlled Trial (RCT) method. The research was conducted in January-February 2021 in Sanan Village, Pakel District and has received approval from the Ethics Committee of the University of Surabaya with code of ethics number $145 / \mathrm{KE} / \mathrm{XII} / 2020$. The sampling technique used is simple random sampling. This study was divided into two groups, namely the control group (placebo) and the treatment group (garlic capsules). The control group took conventional medicine and placebo medicine, while the treatment group took conventional medicine and garlic capsules 3x 500mg for 1 month. Blood pressure measurements were carried out pre-therapy which was measured at week 0 and posttherapy at weeks $1,2,3$, and 4 . The inclusion criteria in this study were hypertensive patients taking conventional drug therapy with uncontrolled blood pressure, Exclusion criteria were hypertensive patients with controlled blood pressure.

Analysis of research data using SPSS software, Paired t-test was used to analyze the difference in blood pressure in the pre-test and post-test with a significant level of 0,05. Independent $t$-test was used to analyze the difference in blood pressure between the treatment group and the control group.

\section{Results and Discussion}

\subsection{Sociodemographic characteristics}

Based on the results of the study, the majority of respondents aged 45-54 years were 38 people $(63,3 \%)$. According to (Dewi, 2010) of 48 respondents with hypertension at the age 
between $45-55$ years as many as 20 people where the older a person's age, the regulation of metabolism of calcium (calcium) is disturbed. This causes the amount of lime that circulates with the bloodstream. As a result, the blood becomes more concentrated and blood pressure increases.

Table 1. Sociodemographic Characteristics

\begin{tabular}{|c|c|c|c|}
\hline Characteristics & $\begin{array}{c}\text { Treatment Group } \\
\text { (Garlic Capsules) } \\
\mathbf{n}=\mathbf{3 0}(\%)\end{array}$ & $\begin{array}{c}\text { Control group } \\
\text { (placebo) } \\
\mathbf{n = 3 0}(\%)\end{array}$ & $\begin{array}{c}\text { Total } \\
\mathrm{n}=60(\%)\end{array}$ \\
\hline \multicolumn{4}{|l|}{ Age } \\
\hline $36-44$ years & $17(28.3)$ & $8(26.7)$ & $25(17)$ \\
\hline $45-54$ years & $18(63.3)$ & $20(66.7)$ & $38(63.3)$ \\
\hline $55-56$ years & $4(6.7)$ & $1(3.3)$ & $5(8.3)$ \\
\hline $66-74$ years & $1(1.7)$ & $1(3.3)$ & $2(3.3)$ \\
\hline \multicolumn{4}{|l|}{ Gender } \\
\hline Male & $5(16.7)$ & $6(20)$ & $11(18.3)$ \\
\hline Female & $25(83.3)$ & $24(80)$ & 49 (81.7) \\
\hline \multicolumn{4}{|l|}{ Last education } \\
\hline Junior high school & $13(43.3)$ & $13(43.3)$ & $26(43.3)$ \\
\hline Senior High School & $16(53.3)$ & $16(53.3)$ & $32(53.3)$ \\
\hline Bachelor & $1(3.3)$ & $1(3.3)$ & $2(3.3)$ \\
\hline \multicolumn{4}{|l|}{ Profession } \\
\hline Housewife & $1(3.3)$ & $7(23.3)$ & $8(13.3)$ \\
\hline Merchants & $6(20)$ & $6(20)$ & $12(20)$ \\
\hline Farmer & $18(60)$ & $11(36.7)$ & $29(48.4)$ \\
\hline entrepreneur & $3(10)$ & $3(10)$ & $6(10)$ \\
\hline Employee & $2(6.7)$ & $3(10)$ & $5(8.3)$ \\
\hline \multicolumn{4}{|c|}{ Long time suffering from hypertension } \\
\hline$<5$ years & $30(100)$ & $30(100)$ & $60(100)$ \\
\hline$>5$ years & $0(0)$ & $0(0)$ & $0(0)$ \\
\hline \multicolumn{4}{|l|}{ Comorbidity } \\
\hline $\begin{array}{l}\text { Yes } \\
\text { (Diabetes mellitus) }\end{array}$ & $30 \quad(100)$ & $\begin{array}{ll}0 & (0)\end{array}$ & $30(50)$ \\
\hline No & $0 \quad(0)$ & $30 \quad(0)$ & $30(50)$ \\
\hline
\end{tabular}

Increasing age causes the elasticity of the arteries to decrease. In order for the need for blood in the tissues to be fulfilled, the heart must pump blood more strongly so that the pressure increases. This is in accordance with the research of Irianto, 2014; Anggara and Prayitno, (2013) with increasing age, blood pressure will increase because the elasticity of blood vessels decreases. Decreased elasticity of blood vessels, making blood vessels unable to dilate, causing blood pressure to rise. The results of this study indicate that with increasing age, the risk of a person experiencing hypertension is greater.

The results of the research that has been carried out, almost the majority of respondents who experience hypertension are female as many as 49 people (81.7\%). According to Raihan and Dewi, (2014) the total sample consisted of 156 respondents, 84 women, indications of 
cardiovascular disease in women increasing after menopause, women who have not been menopausal produce sufficient estrogen hormone to induce the production of good cholesterol (High Density Lipoprotein/HDL). The higher the HDL level, the body has better protection in preventing atherosclerosis. In this study, the respondents who experienced hypertension were women.

The results of research that has been carried out on most of the garlic capsules and placebo groups have the last education of high school, namely 32 people (53.3\%). According to Raihan and Dewi, (2014) of 156 respondents, most of them had a high school education of 55 people, this is in line with research according to Anggara and Prayitno, (2013) where there is a significant relationship between education and blood pressure $(p=0.042)$. The education level of respondents is dominated by high school, education indirectly affects blood pressure because the level of education affects a person's lifestyle, such as smoking habits, alcohol consumption habits, food intake, and physical activity. In the results of direct interviews with respondents, eating habits have a greater influence on the risk of hypertension. In this study, eating habits including a person's lifestyle are influenced indirectly by the last education.

The results of research conducted by most of the respondents as many as 29 people (48.4\%) have a livelihood as farmers. In line with research conducted by (Dermawan, B., \& Hardian, 2013), farmers' livelihoods dominate the work of respondents who stated that there is a relationship between blood acetylcholinesterase activity and systolic pressure with $\mathrm{p}$-value = 0,024. The lower the acetylcholinesterase activity, the higher the blood pressure. According to research conducted by Saldana et al., 2009; Septianaet al.,(2021, there is a relationship between a history of pesticide exposure with an increase in blood pressure in pregnant farmers, continuous exposure to pesticides is at risk of increasing blood pressure. The working period of spraying farmers is related to the amount of accumulation of pesticides that enter the body. In general, the longer farmers do the spraying and it occurs continuously, the higher the risk for poisoning and an increase in blood pressure. According to the results of research by Regi Osang etal., (2016) there is a significant relationship between tenure and blood cholinesterase levels ( $\mathrm{p}$-value = 0.000). Exposure to pesticides does not always directly have a significant impact on the human body without causing sudden pain, chronic poisoning is more difficult to detect because it is not immediately felt and does not cause specific symptoms and signs. However, chronic poisoning in the long term can cause health problems. In this study, the type of work that has a higher risk of experiencing hypertension is farmers, which is caused by continuous exposure to pesticides at risk of increasing blood pressure.

The results of the research that has been done, on the criteria for the length of time span of experiencing hypertension is <5 years as many as 60 people $(100 \%)$, according to research Santoso, 2009; Nurhidayati et al.,(2019) suffered from hypertension for between 1-2 years as many as 51 people out of 85 respondents caused cardiac physiology in the aging process to experience hypertrophy or called heart enlargement, while other organs experienced shrinkage or shrinkage as well as blood vessels that are getting smaller Due to the aging process, the walls of the heart chambers thicken, the heart valves begin to thicken and stiffen, so that the pumping 
power of the heart muscle decreases, causing the elderly to be at risk for coronary heart disease, hypertension, and heart rhythm disorders. In the study of Laka et al., (2018) hypertension is a disease that causes new problems, such as stroke, heart failure, kidney failure and of course all of them have an impact on death. So it is necessary to prevent early so that hypertension does not cause new problems for sufferers. This is what makes people with hypertension anxious about their condition. Therefore, in people who suffer from hypertension, it would be better if the state of high blood pressure can be controlled from the time it is diagnosed with lifestyle changes.

The results of research that has been conducted on the garlic capsule group with comorbid diabetes mellitus (DM) were 30 people, while the placebo group did not suffer from diseases other than hypertension 30 people (50\%). According to Mihardja L, 2009; Putra et al., (2019) hypertension is the main risk factor for the occurrence of DM. The relationship with type 2 diabetes is very complex, hypertension can make cells insensitive to insulin (insulin resistance). Excess insulin levels cause an increase in sodium retention by the renal tubules which can cause hypertension. The results of the analysis according to Mihardja L, 2009; Putra et al., (2019) showed that the incidence of hypertension was more experienced by respondents whose sodium intake was frequent $(61.3 \%)$ than respondents whose sodium intake was not frequent $(9,1 \%)$. The results of this study indicate that hypertensive patients are at risk of suffering from type 2 diabetes mellitus.

\subsection{Mean arterial pressure (MAP) per week}

The results of the research that was carried out in the garlic capsule group, the average MAP decreased from week 0 to week 4 by $21 \mathrm{mmHg}$. While in the placebo group, there was only a slight decrease in changes from week 0 to week 4, namely $1 \mathrm{mmHg}$. There was a decrease in MAP every week after consuming garlic capsules at a dose of $1500 \mathrm{mg} / \mathrm{day}$. The results of this study are in line with the research conducted by Putri (2015) where the average value of MAP before giving garlic capsules is 243,73 while after giving garlic capsules is 108,36 so that there is a decrease in MAP of 135,37 mmHg. The decrease in MAP that occurred in the garlic capsule group was due to the administration of complementary garlic therapy which functions as an antihypertensive, because it contains allicin (Febyan et al., 2015). 


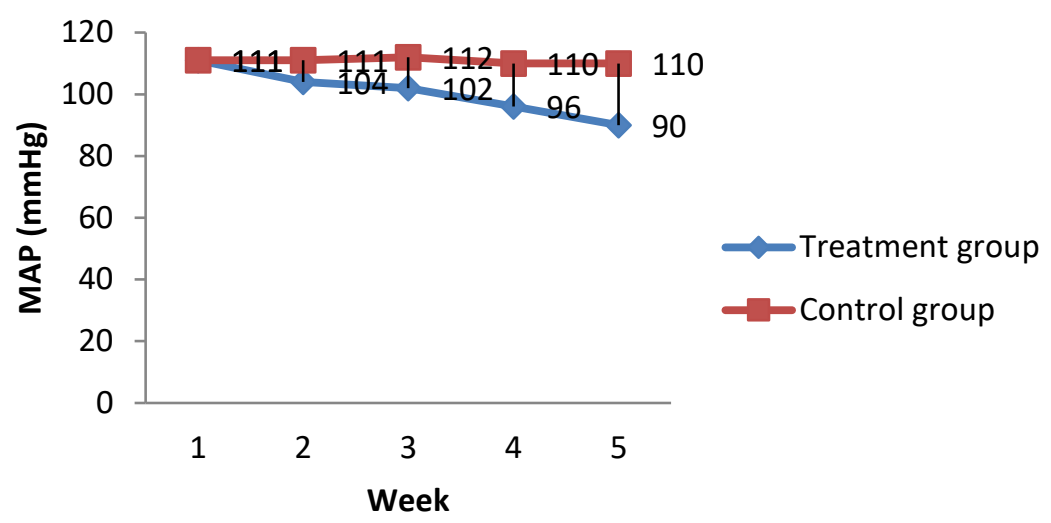

Fig.1. Average Value of MAP Per Week for Hypertensive Patients in the Treatment Group (Garlic Capsules) and Control Group (Placebo)

The results of the research that was carried out in the garlic capsule group, the average MAP decreased from week 0 to week 4 by $21 \mathrm{mmHg}$. While in the placebo group, there was only a slight decrease in changes from week 0 to week 4 , namely $1 \mathrm{mmHg}$. There was a decrease in MAP every week after consuming garlic capsules at a dose of $1500 \mathrm{mg} / \mathrm{day}$. The results of this study are in line with the research conducted by Putri (2015) where the average value of MAP before giving garlic capsules is 243.73 while after giving garlic capsules is 108.36 so that there is a decrease in MAP of $135.37 \mathrm{mmHg}$. The decrease in MAP that occurred in the garlic capsule group was due to the administration of complementary garlic therapy which functions as an antihypertensive, because it contains allicin (Febyan et al., 2015).

\subsection{MAP value before and after administration of garlic capsules}

The results of the analysis obtained that the average decrease in MAP before and after consuming garlic capsules was 20.23 with a $\mathrm{P}$ Value of 0.000 , then there was a significant difference between the MAP value before and after administration of garlic capsules with a $\mathrm{P}$ Value $<0.05$. While in the placebo group with a $\mathrm{P}$ Value of 0.258 , it means that $\mathrm{P}$ Value $>0.05$ there is no significant difference between the MAP value before and after giving placebo capsules with a slight decrease in the MAP value of 0.6. This study is in line with Nugroho's (2014) research on the effect of giving single garlic (Allium Sativum Linn) to lowering blood pressure in hypertension sufferers in Juwet Hamlet, Magersari Village, Plumpang District, Tuban Regency, where from the results of the study obtained from 36 patients studied, some patients a total of 18 people $(50 \%)$ before being given a single garlic (Allium Sativum linn) the average blood pressure of the patients was 169/105 $\mathrm{mmHg}$ (Hypertension Level 2). The respondents' average systolic blood pressure (posttest control) was 151.50 and the respondent's diastolic blood pressure (posttest control) was 99.75. The respondents' average systolic blood pressure (posttest intervention) was 144.25 and the respondent's diastolic blood pressure (posttest intervention) was 91.88. The average calculation of MAP before intervention was $126.3 \mathrm{mmHg}$ and after intervention was $109.3 \mathrm{mmHg}$. According to Kuswardani (2016), garlic contains several compounds that are antihypertensive, such as allisin and allyl-methyl-sulfide. Therefore, garlic 
can be used as a lowering of blood pressure for people with hypertension. At the same time preventing high blood pressure for people whose blood pressure is normal (Kuswardani, 2016).

Table 2. Average Decrease in MAP Before and After Intervention in the Garlic Capsules and Placebo Group

\begin{tabular}{ccccc}
\hline & \multicolumn{3}{c}{ Average MAP } \\
& Mean & Min-Max & $\begin{array}{c}\text { Average } \\
\text { Decrease }\end{array}$ & P Value \\
\hline $\begin{array}{c}\text { Garlic Capsules Group } \\
\text { Before }\end{array}$ & 110.50 & $93-123$ & & \\
After & 90.27 & $83-97$ & 20.23 & 0.000 \\
$\begin{array}{c}\text { Placebo Group } \\
\text { Before }\end{array}$ & 111.03 & $103-127$ & & \\
After & 110.43 & $103-120$ & 0.6 & 0.258 \\
\hline
\end{tabular}

According to the research of John and Sarah (2020), the pathophysiology of hypertension is that angiotensin II in the proximal convoluted tubule of the kidney is able to increase Na-H exchange which ultimately increases sodium reabsorption. In addition to the proximal convoluted tubules of the kidney, angiotensin II acts on the zona glomerulosa of the adrenal cortex, by stimulating the release of aldosterone that increases sodium reabsorption and potassium excretion in the distal tubule and collecting duct of the nephron. Aldosterone works by stimulating the entry of sodium channels and basolateral $\mathrm{Na}-\mathrm{K}$ protein ATPase so that it can increase sodium reabsorption. Aldosterone is a steroid hormone that works by binding to nuclear receptors and altering gene transcription. The increase in blood pressure induced by aldosterone takes a long time to occur, in contrast to angiotensin II which occurs rapidly. In the Cardiovascular System, garlic can affect blood pressure (Varsha, 2012). Allium sativum Linn will decompose into diallyl sulfide, diallyl disulfide and diallyl trisulfide and then combine to form organic polysulfide which causes red blood cells to produce large amounts of hydrogen sulfide. Hydrogen sulfide will activate the K-ATP channel, so the concentration of $\mathrm{Ca}^{2+}$ in the cell will decrease. The decrease in $\mathrm{Ca}^{2+}$ concentration causes hyperpolarization of vascular smooth muscle cells thereby inducing vasodilation of blood vessels so that blood pressure can fall. According to the researcher's analysis, after being given garlic, which was given on the first day to patients with hypertension, it had a significant effect on reducing blood pressure. Based on the results of the study showed that of the 30 respondents who were given garlic capsules, all of them experienced a decrease in blood pressure.

\subsection{Effect of garlic capsules on MAP}

The results of this study have a p-value of 0.000 which means that there is a significant difference in the MAP value after administration of garlic capsules with the administration of placebo capsules. The results of this study are in line with research conducted by Putri (2015) 
after the t-test was carried out, it was found that the average decrease in systolic blood pressure was $9.29 \mathrm{mmHg}$ with $\mathrm{p}$-value $=0.003$ the average decrease in diastolic blood pressure was 3.97 $\mathrm{mmHg}$ with $\mathrm{p}$-value $=0.000$ which means $\mathrm{Ha}$ is accepted, and the average value of MAP before giving garlic capsules is $243.73 \mathrm{mmHg}$ while after giving garlic capsules is $108.36 \mathrm{mmHg}$. The target for reducing mean arterial pressure (MAP) does not exceed 25\% within minutes to 1 hour and if it is stable it can reach blood pressure of 160/100 - $110 \mathrm{mmHg}$ within 2-6 hours, because a faster decrease will cause ischemia of the coronary, brain, and spinal cord. and kidney. The appropriate initial therapy for this condition is to give short-acting nifedipine. If the blood pressure level is tolerated in a stable patient, normal blood pressure can be achieved within the next 24-48 hours. The results of Putri (2015) showed that there was a decrease in the average MAP before and after the administration of garlic capsules. In accordance with what was discussed in Regianto (2006), it showed that consuming 1 capsule containing 1,5 grams of garlic extract 1 time per day for 1 weeks was able to lower blood pressure with an average decrease in systolic blood pressure of $5.45 \mathrm{mmHg}$ and diastolic blood pressure of $7.27 \mathrm{mmHg}$ with an average decrease in MAP of $6.7 \mathrm{mmHg}$.

Table 3. The Effect of Giving Garlic Capsules on the Value of MAP

\begin{tabular}{lcccc}
\hline \multicolumn{1}{c}{ Pre - Post Test } & $\mathrm{N}$ & Average value & Total & p-value \\
\hline Negative value & 30 & 90.27 & 2708.1 & \\
Positive value & 0 & 0 & 0 & 0.000 \\
Same value & 0 & 0 & 0 & \\
\hline
\end{tabular}

An increase in blood pressure occurs when angiotensin-converting enzyme converts angiotensin I to angiotensin II (Mandiri, 2018), this receptor is known to have a vasoconstrictive effect (John and Sarah, 2020).. Garlic capsule extract can lower blood pressure which according to Febyan et al. (2015),, the mechanism of allicin has the same mechanism as ACEi (Angiotensin-converting Enzyme) Inhibitors, namely by inhibiting the work of angiotensinconverting enzyme which plays a role in converting angiotensin I to angiotensin II, causing a decrease in aldosterone secretion in the adrenal glands and reducing sodium and water absorption so that plasma volume will decrease. Like one class of antihypertensive drugs according to Dipiro et al., (2021) Angiotensine Converting Enzym (ACE) Inhibitor. These drugs prevent the conversion of angiotensin I to angiotensin II both systemically and locally in some tissues and plasma. In addition, this drug can reduce peripheral vascular resistance and is able to lower blood pressure without reflex stimulation of heart rate and cardiac output. Examples of ACEI groups are captopril, enalapril, and lisinopril. According to the researchers, by studying the various theories and research results described above, garlic has an effect in reducing blood pressure in hypertensive patients with the right amount of dosage, namely $500 \mathrm{mg}$ of garlic extract and consumed regularly 3 times a day because garlic plays a role in regulating blood pressure. blood pressure so as to improve blood circulation. Based on the results of the study 
showed that from 30 respondents, $100 \%$ of respondents after consuming garlic juice experienced a decrease in blood pressure.

\section{Conclusion}

There is a significant difference in the MAP value with a p-value of 0.000 , which means that there is an effect of complementary therapy on garlic (Allium sativum Linn) capsules on patients with hypertension.

\section{Conflict of Interest}

All Authors declare no conflict of interest and agree with the content of the manuscript.

\section{References}

Ashraf, R. Et Al. (2013) 'Effects Of Allium Sativum (Garlic) On Systolic And Diastolic Blood Pressure In Patients With Essential Hypertension', Journal Of Pharmaceutical Sciences, 26(5), Pp. 860-861.

Depkes, R. (2006) Pharmaceutical Care Untuk Penyakit Hipertensi. Jakarta: Direktorat Bina Farmasi Komunitas Dan Klinik.

Dermawan, B., \& Hardian, H. (2013) 'Hubungan Antara Aktivitas Asetilkolinesterase Darah Dengan Tekanan Darah Petani Yang Terpapar Organofosfat', Doctoral Dissertation, Diponegoro University.

Dewi, S. F. D. (2010) Hidup Bahagia Dengan Hipertensi. Jogjakarta: A+ Plus Books.

Dinas Kesehatan Provinsi Jawa Timur (2017) Profil Dinas Kesehatan Provinsi Jawa Timur Tahun 2016. Surabaya: Dinas Kesehatan Provinsi Jawa Timur.

Dinas Kesehatan Republik Indonesia (2006) Pharmaceutical Care Untuk Penyakit Hipertensi. Jakarta: Dinas Kesehatan Republik Indonesia.

Febyan Et Al. (2015) 'Peranan Allicin Dari Ekstrak Bawang Putih Pengobatan Sebagai Pengobatan Komplemen Alternatif Hipertensi Stadium I', 2015, 42 No. 4(4), P. 303.2.

Irianto, K. (2014) Memahami Berbagai Macam Penyakit. Bandung: Alfabeta.

Ismail, H. F. (2018) Statistika Untuk Penelitian Pendidikan Dan Ilmu-Ilmu Sosial. Jakarta: Kencana.

Joseph T. Dipiro, Gary C. Yee, L. Michael Posey, Stuart T. Haines, Thomas D. Nolin, V. E. (2021) Pharmacotherapy A Pathophysiologic Approach 11th Edition,. Review E-B.

Karina, R. (2013) 'Pengaruh Ekstrak Bawang Putih ( Allium Sativum ) Terhadap Pertumbuhan Bakteri Streptococcus Mutans Secara In Vitro’, Pp. 1-55.

Karyadi (2002) Hidup Bersama Penyakit Hipertensi, Asam Urat, Jantung Koroner. Jakarta: Pt Intisari Media Utama.

Kementerian Kesehatan RI. Pusat Data Informasi (2014) No Title. Available At: Www.Depkes.Go.Id/Resources/Download/Pusdatin/Infodatin/Infodatin-Diabetes.Pdf .

Kementrian Kesehatan Republik Indonesia (2014) 'Situasi Kesehatan Jantung', Pusat Data Dan Informasi Kementerian Kesehatan Ri, P. 3.

Kowalski, R. (2010) Terapi Hipertensi: Program 8 Minggu Menurunkan Tekanan Darah Tinggi. Edited By R. Ekawati. Bandung: Qanita Mizan Pustaka.

Kuswardani (2016) dalam Dwi Christina Rahayuningrum, Andika Herlina (2020) Pengaruh Pemberian Air Perasan Bawang Putih (Allium Sativum) Terhadap Tekanan Darah Pada Penderita Hipertensi..Jurnal Kesehatan Saintika Meditory Volume 2 Nomor 2 
Https://Jurnal.Syedzasaintika.Ac.Id. E-Issn :2655-5840 Issn: 2655-9641

Laka, O. K., Widodo, D., \& Rahayu, W. (2018) 'Hubungan Hipertensi Dengan Tingkat Kecemasan Pada Lansia Di Posyandu Lansia Desa Banjarejo Kecamatan Ngantang Malang', Jurnal Ilmiah Keperawatan, (3(1)).

Lee, D. K. K., Eastham, P. R., \& Cooper, N. R. (2011) 'Breakdown Of Counterflow Superfluidity In A Disordered Quantum Hall Bilayer. Advances In Condensed Matter Physics, 2011.'

Mandiri, R. K. (2018) Analisis Efektivitas Biaya Kombinasi Captopril-Amlodipine Dan Captopril-Furosemide Pada Pasien Hipertensi Rawat Inap Di Rsud Dr. Moewardi Tahun 2015. Universitas Setia Budi Surakarta.

Marieska, H. V. (2019) 'Buktikan 3 Khasiat Minum Air Rebusan Bawang Putih Untuk Tekanan Darah', Jawa Pos.

Mohanis (2015) dalam Dwi Christina Rahayuningrum, Andika Herlina (2020) Pengaruh Pemberian Air Perasan Bawang Putih (Allium Sativum) Terhadap Tekanan Darah Pada Penderita Hipertensi.Jurnal Kesehatan Saintika Meditory Volume 2 Nomor 2 Https://Jurnal.Syedzasaintika.Ac.Id. E-Issn :2655-5840 Issn: 2655-9641

Nurhidayati, I., Aniswari, A. Y., Sulistyowati, A. D., \& Sutaryono, S. (2019) 'Penderita Hipertensi Dewasa Lebih Patuh Daripada Lansia Dalam Minum Obat Penurun Tekanan Darah', Jurnal Kesehatan Masyarakat Indonesia, 13(2), Pp. 1-5.

Nursalam (2017) Metode Penelitian Ilmu Keperawatan Ed. 4. Jakarta: Salemba Medika.

Putra, I.D.G.I.P., Wirawati, I.A.P., Mahartini, N. N. (2019) 'Hubungan Kadar Gula Darah Dengan Hipertensi Pada Pasien Diabetes Mellitus Tipe 2 Di Rsup Sanglah’, Intisari Sains Medis, 10(3)(Doi: 10.15562/Ism.V10i3.482), Pp. 797-800.

Putri, A. (2015) Pengaruh Konsumsi Bawang Putih (Allium Sativum Linn) Terhadap Penurunan Tekanan Darah Pada Penderita Hipertensi Di Wilayah Kerja Puskesmas Gulai Bancah Kota Bukittinggi Tahun 2015, Skripsi. Program Studi Ilmu Keperawatan, Sekolah Tinggi Ilmu Kesehatan Perintis, Sumatra Barat.

Raihan Dan Dewi (2014) 'Faktor-Faktor Yang Berhubungan Dengan Kejadian Hipertensi Pada Laki-Laki Berusia 40-65 Tahun Di Puskesmas Bitung Barat Kota Bitung'.

Rakel D.P And Faass N. (2016) Complementary Medicinen In Clinical Practice. Edited By Jones And And Battlett. Sudbury, Mass.

Regi Osang Et. Al (2016) 'Hubungan Antara Masa Kerja Dan Arah Angin Dengan Kadar Kolinesterase Darah Pada Petani Padi Pengguna Pestisida Di Desa Pangian Tengah Kecamatan Passi Timur Kabupaten Bolaang Mongondow', Pharmacon, (5(2)).

Regianto, B. (2006) Pengaruh Pemberian Bawang Putih Terhadap Penurunan Tekanan Darah Di Puskesmas Mulyorejo Surabaya, Skripsi. Fakultas Kesehatan Masyarakat Universitas Airlangga Surabaya.

Rizal, M. F. (2019) 'Pengaruh Getuk Herbal Mahkota Dewa Terhadap Penurunan Tekanan Darah Pada Lansia Dengan Hipertensi Di Upt Pstw Blitar (Di Blitar Dan Tulungagung)', Penelitian Quasy-Experimental (Doctoral Dissertation, Universitas Airlangga).

Sugiarti (2015) dalam Dwi Christina Rahayuningrum, Andika Herlina (2020) Pengaruh Pemberian Air Perasan Bawang Putih (Allium Sativum) Terhadap Tekanan Darah Pada Penderita Hipertensi..Jurnal Kesehatan Saintika Meditory Volume 2 Nomor 2 Https://Jurnal.Syedzasaintika.Ac.Id. E-Issn :2655-5840 Issn: 2655-9641

Septiana, D., Suhartono, S., \& Dewanti, N. A. Y. (2021) 'Hubungan Pajanan Pestisida Sebelum Masa Kehamilan Dengan Kejadian Hipertensi Pada Ibu Hamil Di Wilayah Pertanian 
Kecamatan Sumowono Kabupaten Semarang', Jurnal Kesehatan Masyarakat (Undip), (9(2)), Pp. 187-194.

Sihotang, M. And Elon, Y. (2020) 'Hubungan Aktivitas Fisik Dengan Tekanan Darah Pada Responden Dewasa'.

Smeltzer, S. C. And Bare, B. G. (2013) Buku Ajar Keperawatan Medikal Bedah Brunner \& Suddarth. 8th Edn. Jakarta: Egc.

Sugiyono (2009) Metode Penelitian Bisnis. Edisi Ketu. Bandung: Cv Alfabeta.

Sutanto (2010) Cekal (Cegah Dan Tangkal) Penyakit Modern. Yogyakarta: C.V. Andi Offset.

Varsha, G. (2012) 'Hyolipidemic Effect Of Garlic: On Experimentally Induced Hyperlipidemia. Jarbs', 4(1), Pp. 5-6.

Who (2005) Clinical Guidelines For The Management Of Hypertension. Kairo: World Health Organization.

Widyatuti (2008) 'Terapi Komplementer Dalam Keperawatan', Keperawatan Indonesia, 12(1), Pp. 53-57.

World Health Organization (2018) Global Health Estimates 2016: Deaths By Cause, Age, Sex, By Country And By Region, 2000- 2016. Geneva. World Health Organization.

Yogiantoro, M. (2014) Pendekatan Klinis Hipertensi: Buku Ajar Ilmu Penyakit Dalam Edisi Keenam Jilid Ii. Jakarta: Interna Publishing. 